PALEO

Revue d'archéologie préhistorique

$14 \mid 2002$

Varia

\title{
Secondary burial in the Magdalenian: The Brillenhöhle (Blaubeuren, Southwest Germany)
}

Une sépulture secondaire magdalénienne: le cas de la grotte de Brillenhöhle (Blaubeuren, sud-ouest de l'Allemagne)

Sekundärbestattung im Magdalenien : Die Brillenhöhle (Blaubeuren, Südwestdeutschland)

\section{Jörg Orschiedt}

\section{(2) OpenEdition}

\section{Journals}

Electronic version

URL: http://journals.openedition.org/paleo/1504

DOI: $10.4000 /$ paleo. 1504

ISSN: $2101-0420$

\section{Publisher}

SAMRA

\section{Printed version}

Date of publication: 1 December 2002

Number of pages: $241-256$

ISSN: $1145-3370$

\section{Electronic reference}

Jörg Orschiedt, « Secondary burial in the Magdalenian: The Brillenhöhle (Blaubeuren, Southwest Germany)», PALEO [Online], 14 | 2002, Online since 17 August 2010, connection on 22 July 2020. URL http://journals.openedition.org/paleo/1504; DOI : https://doi.org/10.4000/paleo.1504

This text was automatically generated on 22 July 2020

\section{(c) (i) (9)}

PALEO est mis à disposition selon les termes de la licence Creative Commons Attribution - Pas d'Utilisation Commerciale - Pas de Modification 4.0 International. 


\section{Secondary burial in the Magdalenian: The Brillenhöhle (Blaubeuren, Southwest Germany)}

Une sépulture secondaire magdalénienne: le cas de la grotte de Brillenhöhle (Blaubeuren, sud-ouest de l'Allemagne)

Sekundärbestattung im Magdalenien : Die Brillenhöhle (Blaubeuren, Südwestdeutschland)

Jörg Orschiedt

I would like to thank A. Czarnetzki, Osteological Collection of the University of Tübingen, for the permission to investigate the finds from the Brillenhöhle as well as for his help. I should like to thank H. Hüttemann from the Institute of Geology and Palaeontology of the University of Tübingen for his help in carrying out the SEM investigations as well as for his constructive criticism. I am grateful to B. Gramsch, Potsdam, and P. Pettitt, Oxford for additional information. I would like to thank C. Lauxmann, Institute of Prehistory, Tübingen, Department of Palaeolithic Archaeology and Quaternary Ecology, for allowing the use of unpublished data from her M. A. thesis. I would also like to thank Julia Drell and Ulrich Magin for their help with the English translation and Bruno Maureille for the resumé.

\section{The Circumstances and Situation of the Find}

The Brillenhöhle, a cave site located on the Swabian Alb in Southwest Germany, was excavated by G. Riek from 1955 to 1963 (fig. 1). The cave contained Aurignacien, Gravettian and Magdalenian layers. During the excavations some human bones were discovered within a fireplace in the centre of the cave on the 7th of April 1956. The skeletal remains were positioned in a strip along the south-eastern edge of the fireplace (Riek 1973, p. 86-87; fig. 2). No other human remains could be recovered from the entire remaining find material. The fireplace was located in the lower section of layer IV which is characterised by Magdalenian tools. Today the exact position of the bone 
fragments can no longer be determined. Only the position of the skull-cap in square M10 and 11 and the mandible fragment in square L11 at the immediate edge of the fireplace were documented (Riek 1973, p. 87, fig. 9) (fig. 2). The finds from this fireplace, which consisted of a $13 \mathrm{~cm}$ thick bone-charcoal layer, were, according to G. Riek, almost exclusively of blades, as well as 16 pieces of flat ivory-strips with carved edges (Riek 1973, p. 87, fig. 31, 1-5), fragments of a whetted bone artefact, and a broken bone needle. The exact composition of the find material from the fireplace, and its immediate surroundings, can only be reconstructed approximately. Owing to the missing documentation, the finds can only be assigned to their stratigraphic layer by square-metres. We can only make a rough statement about the fire place and the surrounding squares. The discovered stone artefacts consist of eight crested blades, 63 blades without cortices, eight blades with cortices, 54 flakes with and without cortices, four trimming flakes, three shatters and two cores (Lauxmann 1988, fig. 35, 38a, 42, 45). The spectrum of artefacts suggests a debris zone in the area of the fireplace.

2 The stratigraphical assignation of the fireplace into the lower section of layer IV which appears in the entire cave (Lauxmann and Scheer 1986, p. 110, fig. 4, 5) enables a clear allocation into the Magdalenian. The sediment consisted of medium-coarse, sharpedged, slab forming limestone rubble with small-space dust depositions (Riek 1973, p. 57-61). Further examinations have demonstrated that the separation of layer IV, by Riek (1973, p. 155), into a lower (Magdalenian containing harpoons) and an upper (later Magdalenian) section is not feasible (Lauxmann and Scheer 1986; Lauxmann 1988). A division of the sections of layer IV is not justified by the divergent concentration of finds as well as the artefact assemblage (Lauxmann 1988:12-14, 104, fig. 7, 51) which clearly verify the cohesion of the upper and lower sections of layer IV. In addition, the original division of the sections on the basis of the sediments does not permit a clear distinction between two different sections within layer IV (Lauxmann 1988, p. 12). 
Fig. 1 - The location of the Brillenhöhle (star) on the Swabian Alb with other Magdalenian cave and open air sites of the area

Fig. 1 - Situation de Brillenhöhle (étoile) dans le Jura Souabe, une autre grotte magdalénienne et sites de plein air

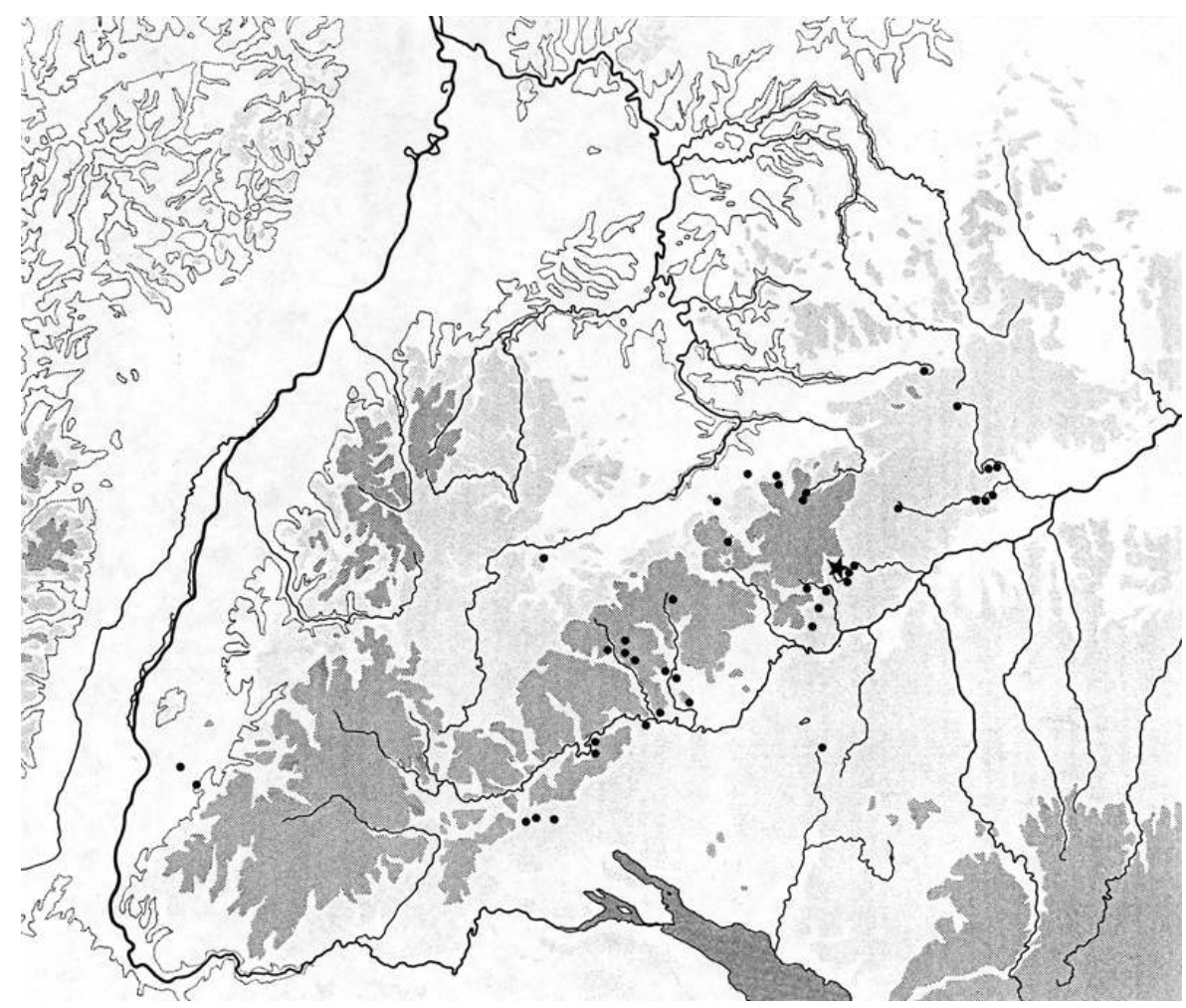

Fig. 2 - The fireplace in the center of the cave containing the human remains (Riek 1973, fig. 9) Fig. 2 - Le foyer, au centre de la grotte, contenant des restes humains (Riek 1973, fig. 9)

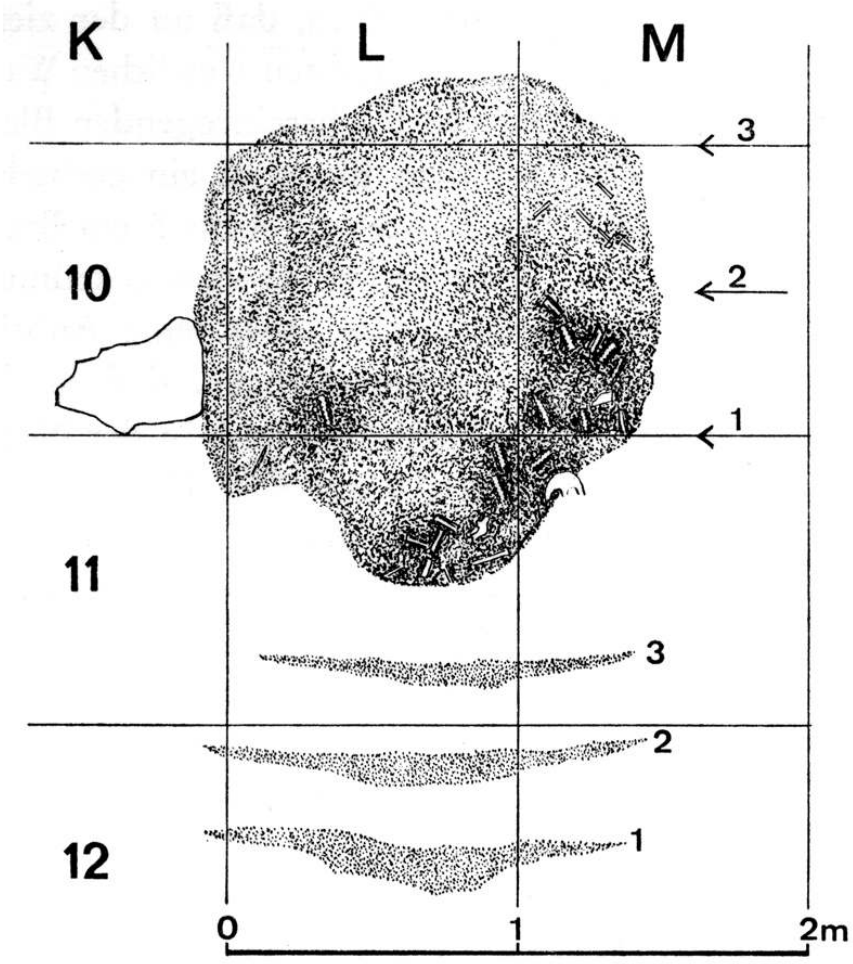




\section{The human skeletal remains}

The human skeletal remains from the Brillenhöhle consist of a total of 38 fragments stemming from the skull and the post-cranial skeleton (fig. 3-4). The attribution to the Magdalenian is correct according to an AMS measurement carried out at the Radiocarbon Accelerator Unit at Oxford on the larger skull fragment which gives an age of $12470 \pm 65$ B.P. (OxA-11054). A not stratified and isolated additional human parietal fragment which was not mentioned in the first publication by Gieseler and Czarnetzki (1973) was found during the analysis within the Brillenhöhle remains. In contrast to the other human remains the skull fragment showed signs of heavy weathering on the outer and inner bone surface. To make sure that this fragment also belongs to the Magdalenian layer another AMS dating was carried out at the Leibnitz Labor für Altersbestimmungen at Kiel. The result was: $1410 \pm 30$ B.P. (KIA 3497). According to this analysis the skull fragment belongs to the early Middle Age (95,4\%: 605-670 A.D. cal.) and probably comes from the top layer of the cave.

Fig. 3 - Skeletal parts of the adult individuals (in black) Fig. 3 - Fragments de squelettes d'adultes (en noir)

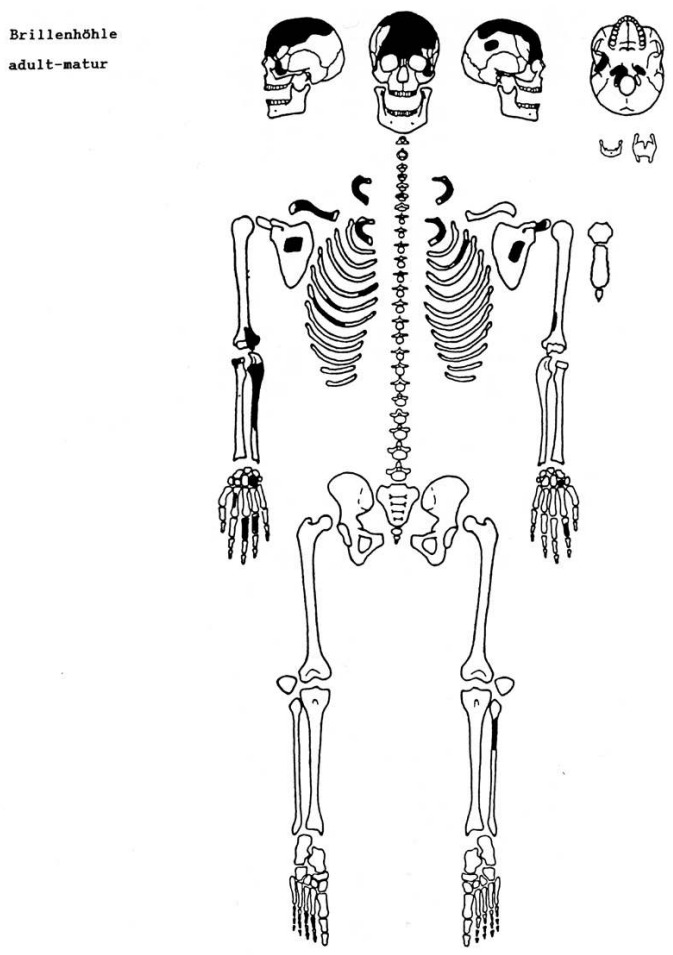


Fig. 4 - Skeletal parts of the infant individual (s) (in black) Fig. 4 - Fragments de squelette(s) d'enfant(s) (en noir)

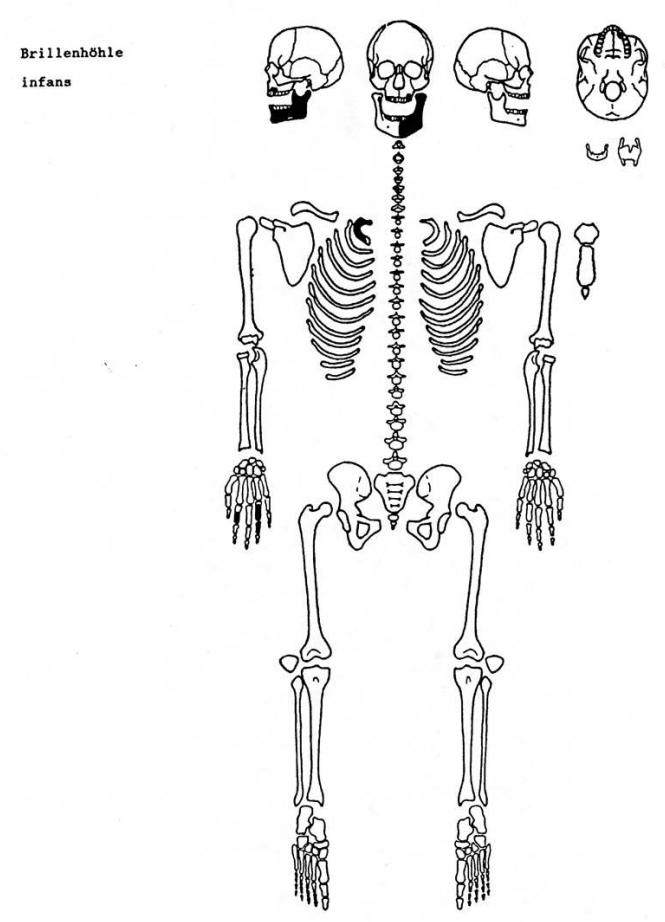

4 All the fragments from layer IV can, apart from their fragmented condition, be described as very well preserved with few signs of weathering or erosion. The number of 1st ribs indicates that the minimum number of individuals (MNI) represented is three: two adults and one child. It is, however, probable that another adult individual is present, since one of the 1st ribs of the right half of the body displays a clear divergence from the 1st ribs of the left half of the body, with regard to its robustness. Hence the piece can not derive from the individuals who are represented by the 1st ribs of the left half of the body (fig. 3). It is striking that no fragment of the very resistant long bone shafts exists, whereas fundamentally more fragile elements of the skeleton, such as that of the 1st rib, are present. The diaphysis of the femur, the tibia, and the humerus should at least be fragmentarily represented under natural conditions. Due to this circumstance it must be assumed that the find material was not accumulated through taphonomical processes, but rather as a result of anthropogenic influence.

A determination of the age of the fragments on the basis of the customary criteria (Szilvássy 1988; Ferembach et al. 1979) is not possible in detail due to the fragmentary condition of the skeletons. The degree of the ossification of the endo- and ecto-cranial sutures of the calotte fragment can merely be assessed, and point towards an age between 40-60 years (mature). The use of the ossification of the cranial sutures has been repeatedly criticised (Kemkes-Grottenthaler 1993, 10-19; Masset 1989), it is obvious that an estimation on this basis can only be regared as a rough indication of the age of the deceased. The mandible fragment allows a more exact estimation. The biological age of this individual can be established with the help of the determination of the dental age (Uebelacker 1978) and can be defined as 8 years \pm 24 months (infant II). The other fragments can be determined as juvenile - mature (14-60 years). The ageclass senile $(>60)$ can be neglected considering that during the Upper Palaeolithic the 
attainment of such an age would certainly be an exception. One of the 1st ribs of the right half of the body, a maxilla fragment, a metacarpus, and a fragment of a cervical vertebrae, and an isolated, not yet erupted, permanent tooth can be defined as immature. These fragments can be allocated to one or several individuals of the ageclass infant I-II (1-14 years) (fig. 4). It is likely that the maxilla and mandible fragments stem from the same individual since they represent the same age-class.

6 The determination of the sex of the skeletal remains by the usual criteria (Ferembach et al. 1979; Sjøvold 1988) is not possible owing to lack of population autonomous sexual features of the preserved fragments. It is furthermore problematic owing to the impossibility of reconstructing the individuals represented. A secure determination of sex is only possible for the skull cap. The formation of the Glabella, the Arcus superciliaris, and the Margo supraorbitalis suggests this individual was male. The right and left Pars petrosa, judging by the configuration of the Porus acusticus internus (Wahl 1982, p. 97-116), can also be determined as male. The remaining fragments cannot be unequivocally allocated to either sex. The character of these can only indicate vague tendencies. The clavicula, the right and left scapula fragment, the ulna and one 1 st rib of the left side of the body, can be described as gracile.

\section{Traces of manipulation}

7 The first anthropological examination of the human skeletal remains revealed cutting and burning traces on some of the fragments, which, in consideration of the situation of the finds in close proximity to a hearth, were interpreted as evidence for cannibalism (Riek 1973, p. 87; Gieseler \& Czarnezki 1973, p. 165-168). This interpretation was only opposed in isolated instances. It was pointed out, with reference to ethnographic analogies, that these traces could also be the result of specific forms of interment or mortuary treatment (Hahn 1988, p. 107).

8 The traces of burning were later rightly identified as soot blackening caused by the surrounding, intensely charcoal-saturated sediment (Czarnetzki 1978, p. 169-170). These particles originate from the dense soot-containing area of the fireplace, in which the bones were embedded. Some further fragments exhibit a dark-brown discoloration, which is related to iron and manganese precipitation. In any case the surfaces of the fragments do not display traces of heat influence such as heat fissures.

9 New analyses of the skeletal remains were undertaken in the context of a dissertation which, while establishing an inventory of the human remains was designed to review previous interpretations of the evidence (Orschiedt 1999, 101-110). The surfaces of all skeletal fragments were examined in macro-, and microscopic detail. Magnifying glasses with up to a 10x magnification and a binocular with up to a 40x magnification were used. In cases where traces of manipulation were suspected, a two-phase cast technique was used (Haidle \& Orschiedt 1995). The casts were examined with a scanning electron microscope (SEM) and documented to enable an interpretation of the traces. These examinations revealed that 25 fragments exhibited cutmarks. Traces of manipulation are evident on the skull cap, the mandible, the Os temporale and Os sphenoidale, the Os zygomaticum, the basal skull, the right and left shoulder blade, the clavicula, the ulna, the fibula, on the four 1st ribs, two further ribs, and on eight phalanges. Accordingly, $64 \%$ of the skeletal fragments exhibit cutmarks in almost all anatomical parts present. Most cutmarks are located in the joint regions of muscle 
insertions or ligament connections. The large quantity of cutmarks on the smaller fragments must be emphasised in this context. The only $5 \mathrm{~cm}$ small fibula fragment thus displays ca. 90 separate cutmarks. In total 622 cutmarks and eleven chopping traces are registered. In addition to these abrasions could be identified which, like the cutmarks, were produced by unretouched chert blades. All traces of manipulation were produced at a point in time when the bone was still 'fresh'. This is verified by the microscopic analysis. All criteria for cutmarks on fresh bones, such as V-shaped cross-section and parallel abrasion on the base of the cutmarks, could be identified (Potts \& Shipman 1981, Shipman 1983).

10 A puncture mark on the left side of the shoulder blade is unambiguous evidence of carnivore activity. This mark indicates the accessibility of the human skeletal remains for animals. The size of the trace suggests that the animal responsible was probably a small dog or fox.

\section{The human skeletal remains from the Brillenhöhle as evidence for the practice of secondary burial}

11 The human skeletal remains of the central fireplace in the Magdalenian-layer IV of the Brillenhöhle were clearly manipulateded by human activity. That the find situation was caused exclusively by taphonomical processes such as movement of the sediments or carnivore activity must be rejected although such traces can be detected on one skeletal element. The accumulation of the human skeletal remains within the hearth would have been disrupted or would never have formed if intense carnivore activity had occurred. In this case, the human skeletal remains would have been scattered within the cave. The cutmarks, chopping traces and abrasions on the skeletal remains indicate division, defleshing, as well as the cleansing of the skeletal remains from attached soft parts, by human agency. The large number of cutmarks suggests that manipulation occurred in a perimortal condition. Evidently these activities were undertaken directly after the death of the individuals. The occurrence of dismemberment and defleshing traces show a considerable anatomical knowledge of the person(s) involved in this activity. The knowledge of the anatomical make-up of large mammals should have been common owing to the hunting and gathering way of life. Since the anatomical composition of humans only insignificantly differs from that of the main prey animals of the Magdalenian, the reindeer and the horse, the correct and quick dissection of the human corpse should not have presented a vast technical challenge.

In the following a general comparison with the faunal assemblages, which also display cutmarks, shall be undertaken in order to test the cannibalism-theory originally proposed by W. Gieseler and A. Czarnetzki (1973). Unfortunately, no comparison could be undertaken with the material from the Brillenhöhle as the investigation of the faunal material was not carried out under taphonomic considerations (Boessneck \& von den Driesch 1973). A comparison with contemporary faunal material represents the only possibility to diagnose cannibalism in the case of archaeological inventories since the presence of cutmarks and burning, as well as the registration of fragmentation, hardly suffice (Villa et al. 1986a, p. 431; 1986b, p. 167; 1988, p. 57; Villa 1992, p. 95). with faunal assemblages from the Magdalenian, substantial differences regarding the 
frequency of cutmarks and a general accordance regarding the location of the traces are evident. The location necessarily results from anatomical preconditions which are fundamentally similar among vertebrates. These concern not only the joint areas and ligamental attachments but also areas of muscle insertion. As a result of the dissection and defleshing of a body cutmarks are inevitable in these areas. Regarding the frequency of these cutmarks there are substantial differences not between different animal species but over time. An investigation of reindeer remains at the Madgalenian site Schussenquelle revealed cutmarks were present at a total of $26 \%$ of the remains (Schuler 1994, fig. 18), while at the Peterfels $21 \%$ of the reindeer bones and $22 \%$ of the horse bones bore cutmarks (Berke 1987a, p. 8-13). On the other hand, only a total of 7\% of the skeletal remains of the Felsställe, associated with the Magdalenian and the early Mesolithic, bear cutmarks. This low frequency seems to be the result of differential states of preservation, which is paralleled by the extremely low frequencies at some horizons at Solutré (Berke 1987a, p. 5; 1987b, p. 304-305; Olsen 1989, p. 306-310). These low and varying cutmark frequencies are to some extent the product of the different find situations, the different methods of processing the material, the different character of the sites leading to diverging operations, as well as the distinct anatomical preconditions of the individual animal species. It needs be pointed out that, especially by the dissection of the animal, cutmarks have not to be produced on all bones, nor on all anatomically relevant regions of the bones,. Experimental butchery with chert-tools and investigation of archaeological faunas suggest that cutmarks are only regularly produced in the area of the joint articulations but even in this area they present a mere coincidence of the process rather than intention (Schütz et al. 1990, p. 248-249; von den Driesch \& Boessneck 1975, p. 18).

These findings show that the cutting trace frequency of $64 \%$ on the human skeletal remains of the Brillenhöhle are certainly not the result of a 'normal' dissection process. The activities were considerably more intense and can only be accounted for by intention and particular prudence. The aim was evidently to free the skeletal remains as far as possible from their tissue. This means that these activities were carried out immediately after the death of the individuals. The high frequency of cutmarks makes it unlikely that the natural process of tissue decomposition and joint disarticulation were already well advanced. The aim to free the skeletal remains as completely as possible of all tissue is further substantiated through the evidence of abrasion (fig. 5-6). 
Fig. 5 - Scraping marks on the ulna (scale 2: 1 ) Fig. 5 - Traces de raclage sur l'ulna (échelle $2: 1$ )

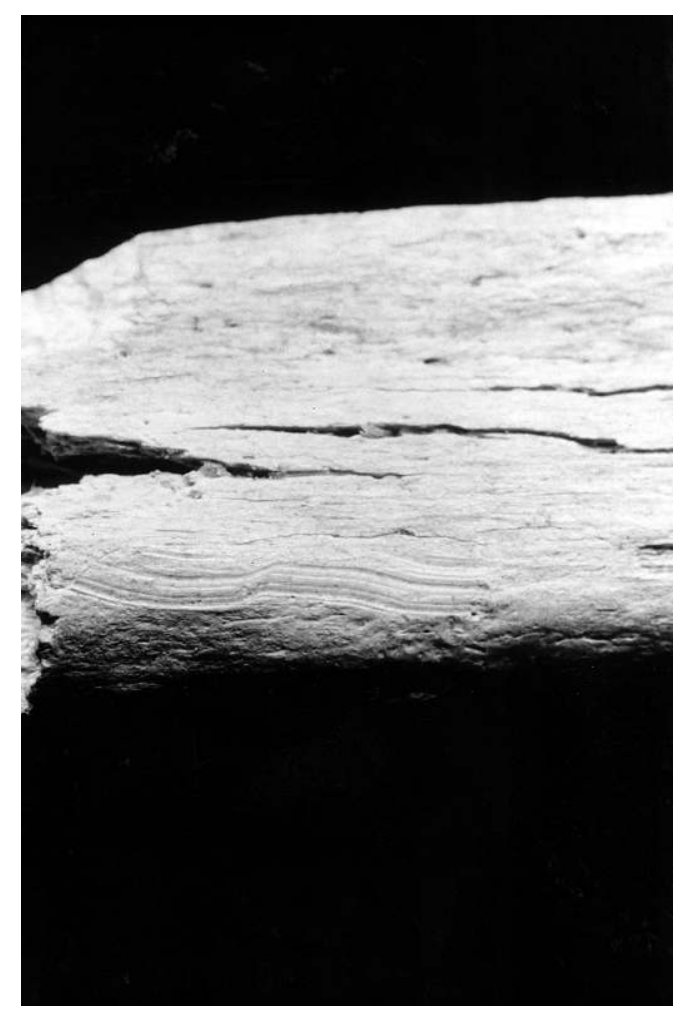

Fig. 6 - SEM image of scraping marks on the ulna Fig. 6 - Image MEB de traces de grattage sur l'ulna

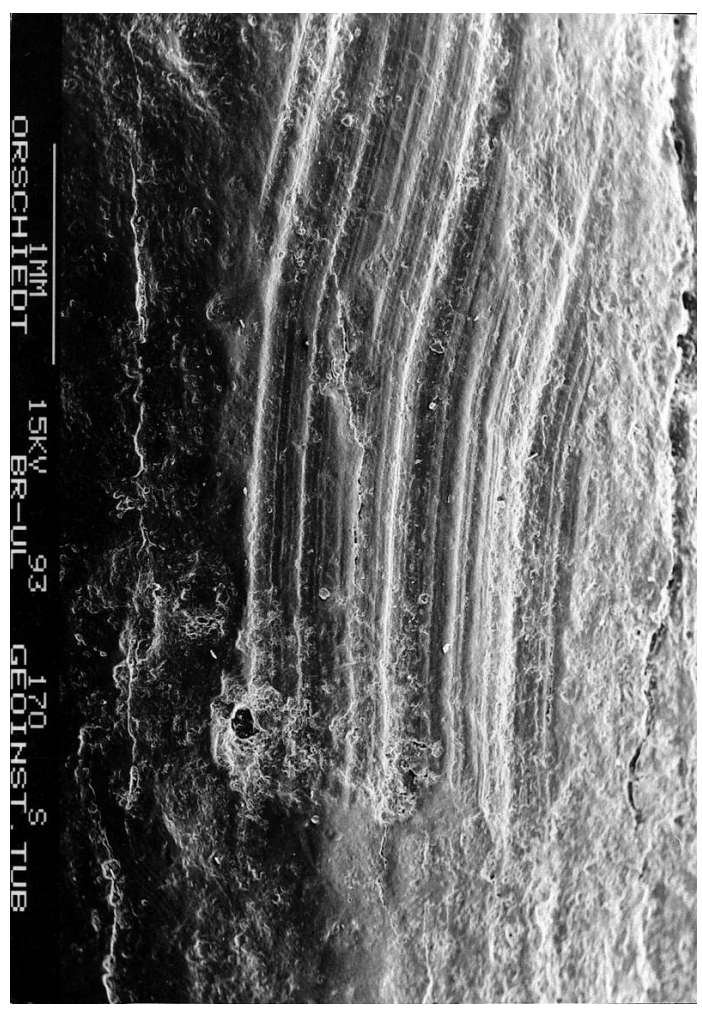


15 According to P. Shipman and J. Cook such abrasions are caused by a stone artefact which is dragged across the longitudinal axis in a right-angle (Shipman 1981, p. 369; Cook 1986, p. 151, fig. 11b). The result is a dense aggregation of flat, parallel abrasions, without a central deepening, on a larger bone surface parallel to the longitudinal axis of the bone. This definition could also be experimentally demonstrated (Orschiedt 1999, 17, tabl. 4). However, the number of publications dealing with such abrasive traces is rather poor (Binford 1981, p. 134). Until now hardly any published works deal with such traces found on the faunal inventories of the Magdalenian (Berke 1987a; 1987b; Schuler 1994). One exception is the late glacial find of a partial skeleton of an ancient bull from Potsdam-Schlaatz (Gustav 1987). Here unequivocal butchering traces in form of cutmarks and abrasions were diagnosed on the skeletal remains (Gramsch 1987, p. 50-51, fig. 9). Abrasions were identified specifically in the region of the ribs and on several components of the vertebrae; these were the result of an intensive dissection and defleshing of the torso of the animal (Gramsch 1987, p.50). In how far the characteristics of these abrasions match those of the Brillenhöhle must be clarified by a scanning electron microscopic (SEM) investigation.

16 The recognition of abrasive traces in any case depends on the state of preservation of the faunal assemblages as the traces can only be recognised very superficially. Confusion with trampling traces or rodent gnawing cannot, among other things, be excluded. L. R. Binford mentions a case from the Middle Palaeolithic site at Combe Grenal (Binford 1981, p. 134). P. Shipman (1981, p. 369) refers to abrasive traces on the faunal assemblages of Olduvai, DK Level 3, FLK 'Zinj', MNK Main (Potts \& Shipman 1981, tabl. 1). Abrasions on human skeletal remains, for example from North-American Indian secondary burials, have not yet been published. The only parallel is a human tibia from the Neolithic context at Salzkotten-Oberntudorf (Orschiedt 1998; 1999, tabl. $25,1)$. Parallels to such abrasions on bones exist in other contexts, for example, as a result of the production of projectile points (Orschiedt 1999, tabl. 25, 2) and on an Upper Palaeolithic bone engraving (Fritz et al. 1993). If the removal of the periostis were necessary for the breaking up of the long bone in order to extract the bone marrow (Binford 1981, p. 134-136), then such abrasive traces should regularly be found on faunal inventories. The rare registration of such kind of traces reveals that a 'nonremoval' of the periost has no influence on the extraction of the bone marrow. This is substantiated by the abrasions found on the vertebrae and ribs of the aurochs from Potsdam-Schlatz (Gramsch 1987, p. 50-51, tabl. 9). Moreover, there are no signs of a deliberate breaking of the bones among the human skeletal remains of the Brillenhöhle, while the bigger long bones are absent from this assemblage. A removal of the periost in order to prepare the bones for marrow extraction can thus not be demonstrated. In addition, abrasive traces are only present on the 1st rib, the scapula and the ulna; skeletal parts which are unsuitable for marrow extraction anyway.

Another striking phenomenon on the human skeletal remains of the Brillenhöhle are cutmarks on the phalanges (fig. 7). Cutmarks in this area are rare in faunal inventories and are only associated with skinning activities. By contrast, phalanges, especially the first phalanges, are frequently crushed for marrow extraction and are also, occasionally, for fibula accrual (Berke 1989, p. 189; 1987a; Münzel 1987, p. 103). The relative low number of phalanges among all archaeological inventories is particularly noticeable, making an evaluation of such processes difficult. Ethno-archaeological investigations by L. Binford among the Nunamiut reveal that cutmarks on phalanges 
are related to extremely detailed skinning of the reindeer and the production of socks and shoes, an activity which would be almost exclusively executed in autumn and early winter (Binford 1981, p.126). Osteologically examined faunal materials from the Magdalenian from the Schussenquelle, for example, only contain a total of seven phalanges, of which only one shows cutmarks (Schuler 1994, tabl. 18). The faunal material from Petersfels contains a second horse phalange with broad and intensive cutmarks at the distal surface of the joint. These were produced as the foot was detached from the fur (Berke 1987a, p. 28). There are only two further reindeer fragments exhibiting cutmarks from this site (Berke 1987a, p.50). Cutmarks on phalanges are also rare among material from other time periods and geographical locations. One example is the site Umingmak, Canada. Among the prevalent musk-ox fauna phalanges rarely exhibited any cutmarks although the 1st phalange is relatively frequently represented within this assemblage. Usually a separation of the phalanges's joints did not occur (Münzel 1987, p. 87-88, tabl.18; 19). Among the reindeer fauna at the same site phalanges were merely separated at the distal metarcarpal (Münzel 1987, p. 145). Considered as a whole the cutmark frequency on phalanges among faunal inventories has to be regarded as extremely low; percentages are usually clearly under 5\% (e.g. Olsen 1989, p. 312, fig. 9; von den Driesch \& J. Boessneck 1975, tabl. 1-3; Valensi 1991, p. 814; Marshall 1986, tabl. 2-3; Cruz-Uribe \& Klein 1994, tabl. 4). The phalanges and other foot bones were probably discarded in their original anatomical association after severing the sinew and ligament connections in the skinning process (von den Driesch \& Boessneck 1975, p. 19). In contrast to the in part extremely low cutmark frequency on the phalanges among faunal inventories of only $0,1 \%$ - ca. $5 \%$, the human hand and foot phalanges of the Brillenhöhle display a cutmark frequency of $72 \%$. This high frequency and the number of cutmarks on the individual phalanges clearly reveal the intensity of dissection in this anatomical region. 
Fig. 7 - Cutmark on a phalange (scale 2:1)

Fig. 7 - Trace de découpe sur une phalange (échelle $2: 1$ )

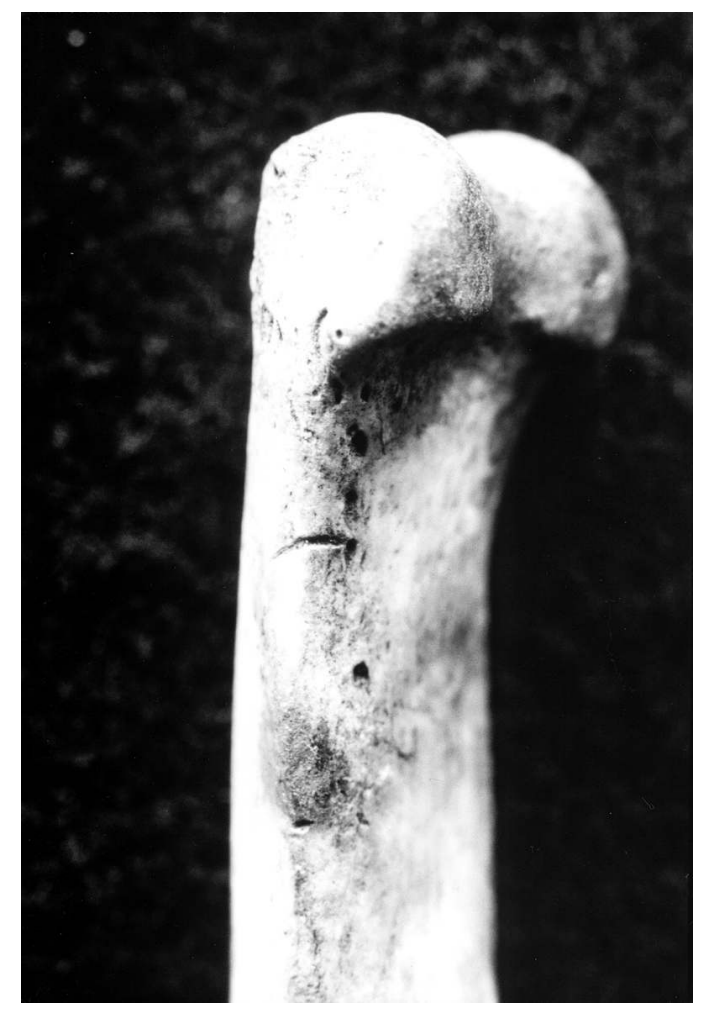

Cutmarks on human skull calottes are usually associated with scalp-removal (White 1992, p. 206). However, in most archaeological cases it remains unsolved which motives led to the removal of the scalp. The most popular interpretation remains the obtainment of war-trophies (Owsley \& Berryman 1975; Hamperl 1967; Anger \& Diek 1978). Yet secondary burial, or the deposition of human skeletal remains, also requires the removal of soft tissue and therefore the removal of the scalp. The cutmarks on the skullcap of the Brillenhöhle can be explained as scalping or skinning traces. The location of the traces on the frontal and parietal bone support this interpretation strongly (fig. 8-9). A comparison with cutmarks on skulls from faunal remains indicates that these were mainly caused by skinning activities. These skinning traces mainly occur in the area of the maxilla, of the frontal bone in the orbital-region and on the base of the antlers (Binford 1981, p. 106-107, fig. 4.11; Trolle-Lassen 1987, fig. 5, 8; Münzel 1987, p. 85, tabl. 1-2). The other traces on the skull, especially in the area of the occipitals and the Condylus occipitalis, result from the detachment of the skull from the vertebral column (Binford 1981, p. 107, fig. 4.11). Owing to the low quantity of meat, defleshing of the skull only makes sene with certain and only a few animal species. This is, for example, the case for musk-oxen on whose skulls traces from the removal of neck and cheek muscles can be found on the maxilla, parietal, and temporal bones (Münzel 1987, p. 98, tabl. 1-2). The investigated southern German Magdalenian inventories from the Schussenquelle and the Petersfels allow to relate cutmarks on reindeer and horse skulls with skinning activities (Schuler 1994, p. 94, tabl. 18; Berke 1987a, p. 8). Therefore, there is thus correspondence between the interpretation of cutmarks in the outlined regions of both human and animals skulls. Since the pragmatic aspect of human skin and, more specifically, the scalp appears rather insignificant, another utilization must be assumed. One such usage could be the already 
mentioned role of the scalp as a 'war-trophy'. However, as the skeletal remains from the Brillenhöhle do not display any traumatic lesions such an interpretation has to remain mere speculation. It is more likely that the removal of the scalp was motivated by the same reasons which also led to the dissection of the body and the complete removal of all soft tissue.

Fig. 8 - Cutmarks on the frontal bone (scale 2:1)

Fig. 8 - Traces de découpe sur l'os frontal (échelle $2: 1$ )

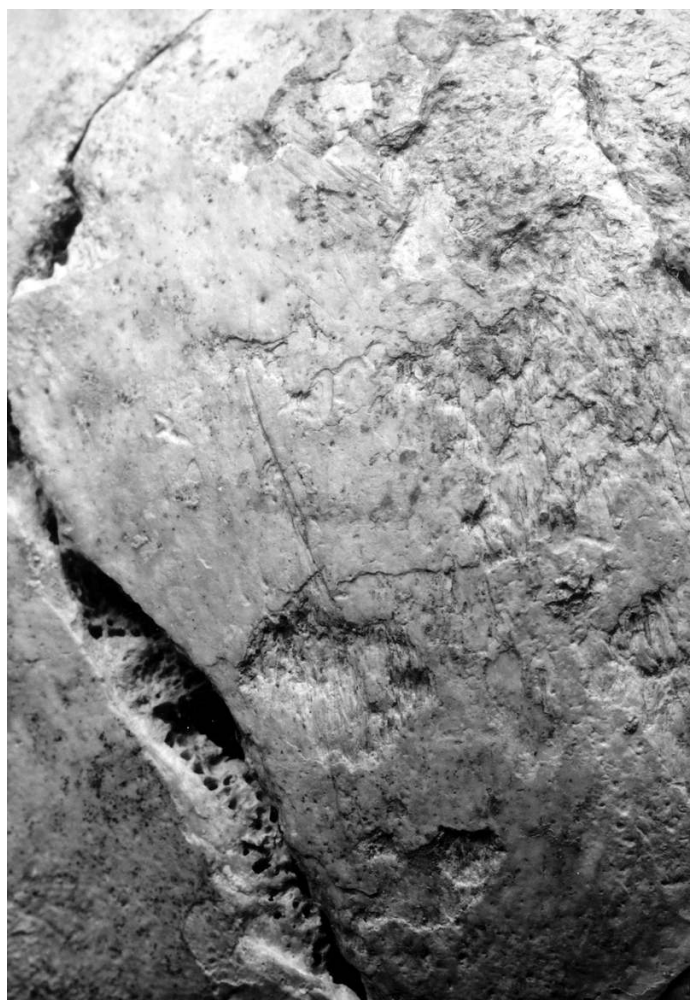


Fig. 9 - SEM image of cutmarks on the frontal bone Fig. 9 - Image MEB de traces de découpe sur l'os frontal

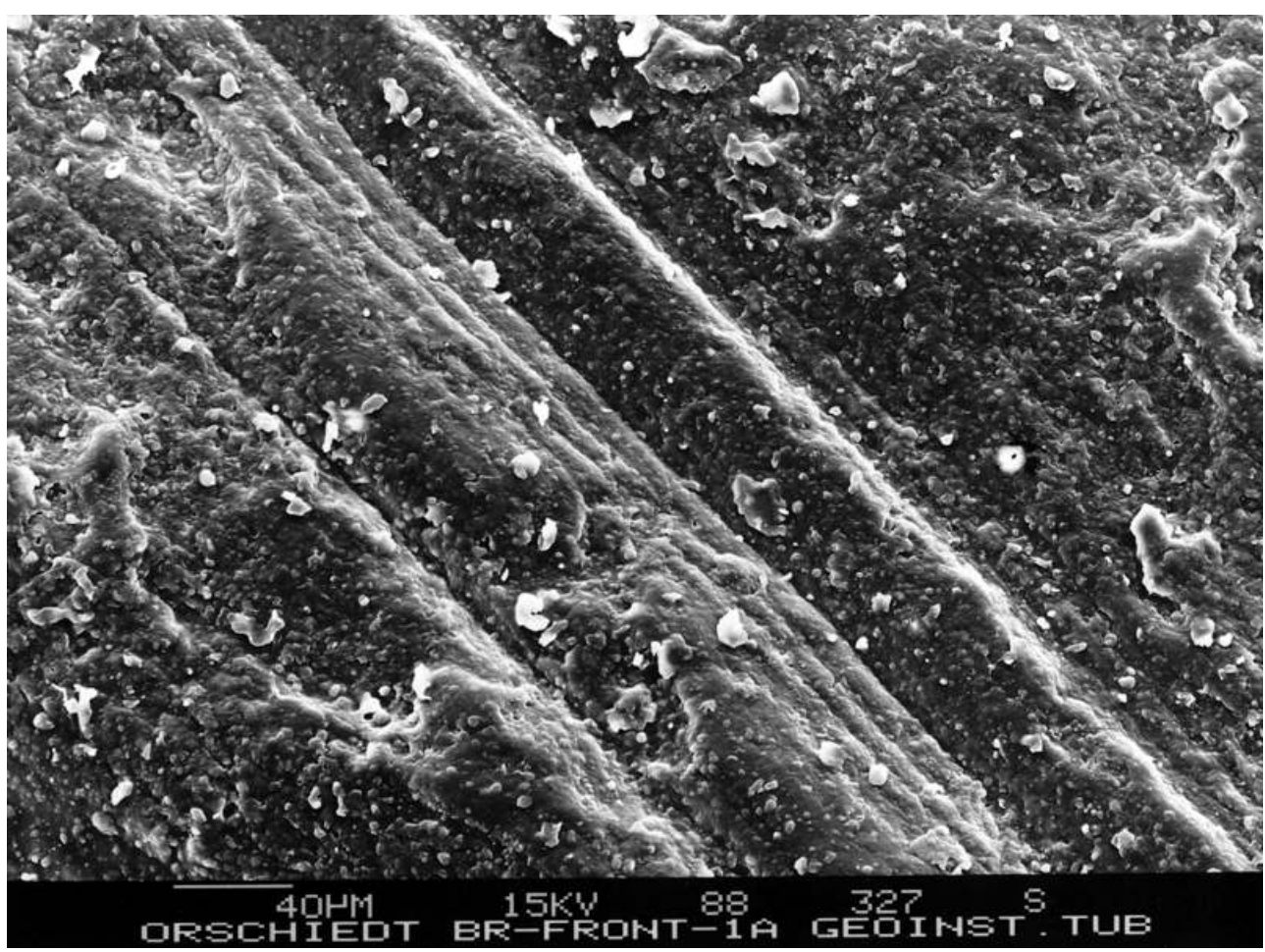

Apart from the interpretation of the modification, the composition or representation of the anatomical elements is of interest. The absence of all large long bones and their fragments and the presence of all smaller bones of the post-cranial skeleton are particularly remarkable. It is furthermore intriguing that hardly any anatomical element is completely represented. It is therefore of great interest why exactly these parts of the skeleton did reach the find spot. Human influence must in any case be considered; this is verified by the situation of the find as well as the absence of those parts of the skeleton, such as the diaphysis/shafts of the long bones, which are more impregnable against taphonomical influences. The concurrent criterion of all represented bones is their small size. In an experiment all skeletal remains present were placed into the skull fragment (fig. 10). It was demonstrated that all pieces fitted into the skull fragment. It was hardly possible to add any further skeletal elements so that a maximal filling can be assumed. On these grounds it can be presumed that the calotte fragment might have served as a transport-container for the skeletal remains which were distributed and deposited on the edge of the fireplace. 
Fig. 10 - Fragment of the skullcap with hole skeletal elements Fig. 10 - Fragment d'une calotte crânienne contenant tous les restes osseux

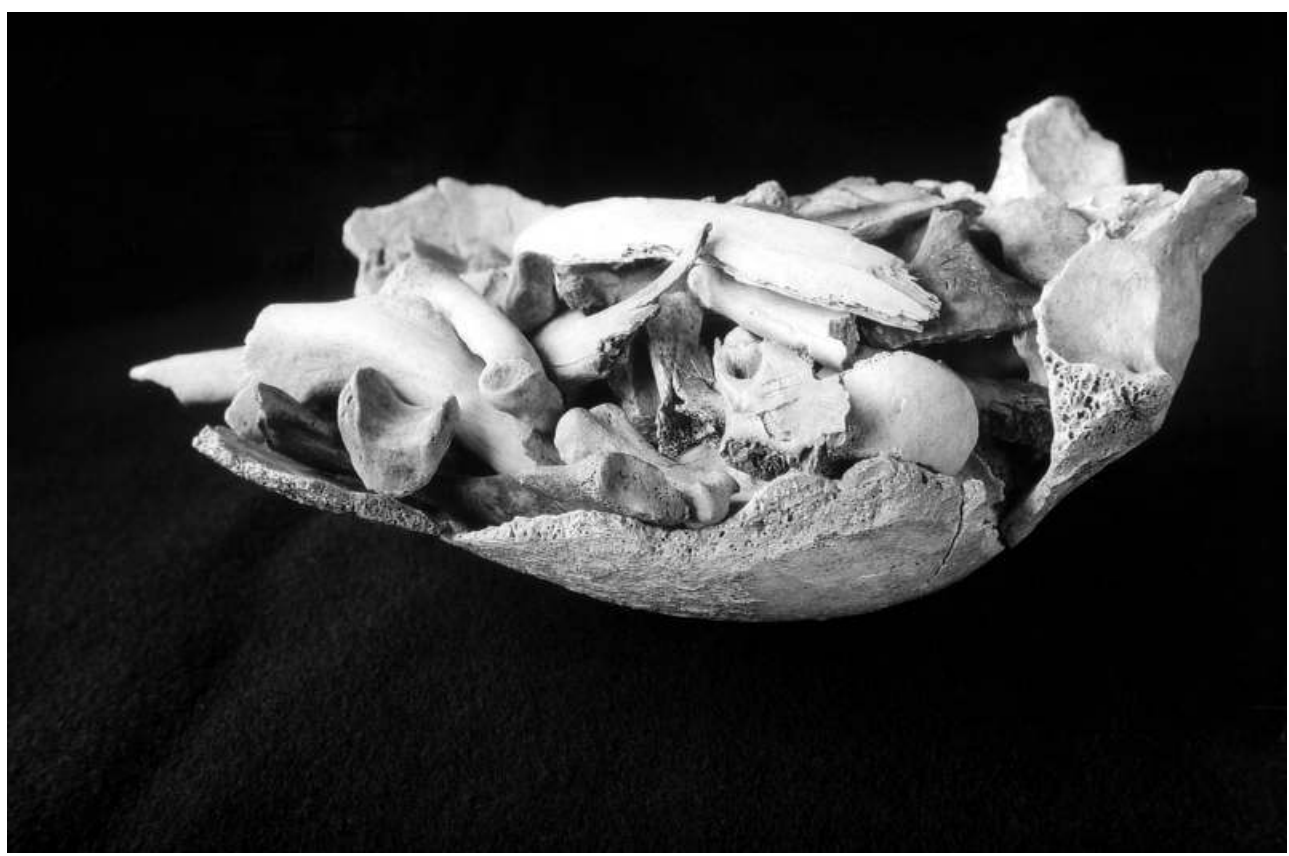

Accordingly, the human skeletal remains from the Brillenhöhle can no longer be quoted as an instance of anthropophagy during the Magdalenian. Indeed, this inventory provides evidence for secondary burial practices during the Upper Palaeolithic as documented ethnographically, for example, among the Batak of Sumatra (Sibeth 1990) and Australian Aborigines (Berndt \& Berndt 1964, p. 392-396; Habenstein \& Lamers 1963, p. 376-379; Pickering 1989). The term 'secondary burial' is hereby used for burials which are described as multiphasal or multistagal. During this process it is important that the originally buried corpse or its remains are recovered and reburied at another place. Frequently not the entire still preserved skeletal remains of one or several deceased are reburied. The application of the term 'secondary burial' to the remains from the Brillenhöhle is justified due to the situation of the find as well as the demonstrable cutmarks - whose intensity exceeds the known extent of utilisation among animal bodies - and the occurrence of abrasions which testify to the removal of any remaining soft tissue residues. The absence of characteristic and weatheringresistant parts of the body - such as the long bones - certifies that a selection of the skeletal elements was undertaken. On these grounds, taphonomical actions can be eliminated as the processes which led to the composition of the find situation. The fragmented condition of the skeletal remains permits the inference that the deposited skeletal remains from the Brillenhöhle had already been stored elsewhere or, alternatively, had been transported by the group for some time. The attested gnawing marks testify to carnivore activity and indicate accessibility of the bones for scavengers before there final deposition. Damage, as well as loss of volume, of the bones in the area of the fireplace can be excluded since the find situation of the skeletal remains in form of a stripe on the edge of a structure strongly indicates anthropogenic influence.

21 This result does by no means constitute an isolated phenomenon during the Palaeolithic period. Apart from the find of a skull of an archaic Homo sapiens or Homo heidelbergensis from Bodo, Ethiopia (600 ka), which exhibits cutmarks (White 1986), and the Atapuerca, Gran Dolina, Spain (TD 6) remains (Fernández-Jalvo et al. 1999) 
(around $800 \mathrm{ka}$ ), cutmarks on an early hominid, Stw 53 (H. cf. habilis or late Australopithecus) from Sterkfontein, South Africa were recently identified (around 2 My) (Pickering et al. 2000). Moreover cutmarks can be observed on several Neanderthal skeletal remains, as, for example, at Combe Grenal (Le Mort 1989; Garralda \& Vandermeersch 2000), Marillac (Le Mort 1988, p. 48-49; 1986, p. 212-213), Abri Moula (Defleur et al. 1993, p. 1999), Neanderthal (Czarnetzki 1977; Schmitz \& Pieper 1992) and Krapina (Ullrich 1978; Trinkaus 1985; Russell 1987a; 1987b, Patou-Mathis 1997). There are also numerous Upper Palaeolithic human remains with cutmarks, as from the Burghöhle Dietfurt in Germany (Taute 1990, p. 39-41; Gietz 2001) and the Maszycka cave in Poland (Kapica \& Wiercinski 1995, p. 249-251; Kozlowski \& Sachse-Kozlowska 1995) as well as several other sites in France as Lauchad, La Madeleine 3, Reignac, SaintMarcel, L' Hermitage, La Marche, Lalinde, Rigney, Piette, Le Morin 1, Roc de Coubert, Isturitz and Le Placard (Le Mort \& Gambier 1992, tabl. 1; Gambier \& Houet 1993, p. 62-65, 70-71). The interpretation of these finds is fairly controversial and ranges from cannibalism to mortuary practices (Orschiedt 1999, 67-72). For most of these inventories there are no definite SEM analyses which would complete the investigation results satisfactorily.

For a comparison with the finds from the Brillenhöhle the skeletal remains from Gough's Cave, Somerset, are of great importance. Here skull fragments and post-cranial skeletal remains from Creswellian layers also display cutmarks (Currant et al. 1989; Cook 1991a; 1991b). These skeletal remains were discovered in the immediate vicinity of the cave entrance during excavations in the years 1986-87. They represent four adults and a juvenile individual. The cutmarks were registered during macroscopic, binocular and SEM investigations. The traces are situated in nearly identical positions on the skullcap, the mandible, and the ribs as is the case on the material from the Brillenhöhle (Cook 1991a, fig.15.2-15.3). As these finds are only published in preliminary reports, no statements can be made about the frequency and distribution of the cutmarks on the post-cranial skeletal remains (Cook 1991a, p. 166). However, the illustrations clearly reveal that apart from the congruence of the location of the traces resulting from anatomical preconditions, a high cutmark frequency is also present (Cook 1991a, fig. 15.2-15.3). As with the contemporary human skeletal remains from the Brillenhöhle, the existing cutmarks can be interpreted as testimony to dissection and defleshing activities (Cook 1991a, p. 166-167). The cutmarks on the skull calotte which are not in the area of the muscle insertions can also be understood as marks caused by the removal of the scalp. The finds from Gough's Cave thus constitute approximately contemporary parallel evidence to that of the inventory of human skeletal remains from the Brillenhöhle.

It has thus been demonstrated that secondary burial has to be included among the mortuary practices of the Upper Palaeolithic and especially of the Magdalenian. Furthermore it has to be assumed that some of the already published inventories of fragmented human skeletal remains from the Palaeolithic with manipulatory traces must be interpreted as secondary burials. Jersey : Princton University 1992. 


\section{BIBLIOGRAPHY}

ANGER W. \& DIECK A. 1978 - Skalpieren in Europa seit dem Neolithikum bis um 1767 n.Chr. Eine Materialsammlung. Bonner Hefte zur Vorgeschichte, 17, 1978, p. 153-240.

BERKE H. 1987a - Archäozoologische Detailunter-suchungen an Knochen aus südwestdeutschen Magdalénien Inventaren. Urgeschichtliche Materialhefte 8. Tübingen: Archaeologica Venatoria, 1987.

BERKE H. 1987b - Die Großsäugerreste aus den spätpleistozänen und holozänen Horizonten der Grabungen am « Felsställe » bei Ehingen-Mühlen, Alb-Donau-Kreis. In: C.-J.Kind, Das Felsställe. Eine jungpaläolithisch-frühmesolithische Abri-Station bei Ehingen-Mühlen, Alb-Donau-Kreis. Die Grabungen 1975-1980. Forschungen und Berichte zur Vor- und Frühgeschichte Baden-Württemberg 23, p. 303-338. Stuttgart: Konrad Theiss 1987.

BERKE H. 1989 - Solutré-Petersfels-Pekarna-Kniegrotte. Schlachtspuren an Pferdeknochen. Archäologische Informationen, 12/2, 1989, p. 180-194.

BERNDT R.M. \& BERNDT C.H. 1964 - The World of the First Australians. An introductionto the traditional life of the Australien Aborigines. London: Angus \& Robertson 1964.

BINFORD L.R. 1981 - Bones. Ancient Men and Modern Myths. New York: Academic Press.

BOESSNECK J. \& VON DEN DRIESCH A. 1973 - Die jungpleistozänen Tierknochenfunde aus der Brillenhöhle. In : G. Riek, Das Paläolithikum der Brillenhöhle bei Blaubeuren Teil 2. Forschungen und Berichte zur Vor- und Frühgeschichte in Baden-Württemberg 4/II. Stuttgart: Konrad Theiss Verlag 1973.

COOK J. 1986 - The application of scanning electron microscopy to taphonomic and archeological problems. In : D.A. Roe (ed.), Studies in the Upper Paleolithic in Britain andnorth-west Europe. BAR Series 296: 143-163. Oxford 1986.

COOK J. 1991a - Preliminary report on marked human bones from the 1986-1987 excavation at Gough's Cave. In : N. Barton, A.J. Roberts \& D.A. Roe (ed.), The Late Glacial in north-west Europe: human adaptation and environmental change at the end of the Pleistocene. CBA Research Report 77. p. 160-168. Oxford: Alden Press 1991.

COOK J. 1991b - Preliminary Report on Marked Human Bones from the 1986-1987 Excavations at Gough's Cave, Somerset, England. Anthropologie (Brno) 29/3, 1991, p. 181-187.

CRUZ-URIBE K. \& KLEIN R.G. 1994 - Chew Marks and Cutmarks on Animal Bones from the Kasteelberg B and Dune Field Midden Later Stone Age Sites, western Cape Province, South Africa. Journal of Field Archaeological Science 21, 1994, p. 35-49.

CURRANT A.P., JACOBI R.M. \& STRINGER C.B. 1989 - Excavations at Gough's Cave, Somerset 1986-87. Antiquity 63, 1989, p. 131-136.

CZARNETZKI A. 1977 - Artifizielle Veränderungen an den Skelettresten aus dem Neandertal? In : P.Schröter (ed.), Festschrift 75 Jahre Anthropologische Staatsammlung München, p. 215-219. München : Selbstverlag der Anthropologischen Staatssammlung 1977.

CZARNETZKI A. 1978 - Die menschlichen Skelettreste aus der mesolithischen Kulturschicht der Falkenstein-höhle bei Thiergarten an der oberen Donau. In: W.Taute, Das Mesolithikum in Süddeutschland Teil 2: Naturwis-senschaftliche Untersuchungen. Tübinger Monographien zur Urgeschichte 5/2, p. 169-174. Tübingen: Archaeo-logica Venatoria 1978. 
DEFLEUR A., DUTOUR O., VALLADAS H. \& VANDERMEERSCH B. 1993. Cannibals among the Neanderthals. Nature 362, 1993, p. 214.

DEFLEUR A., WHITE T., VALENSI P., SLIMAL L. \& CREGUT-BONNOURE É. 1999 - Neanderthal cannibalism at Moula-Guercy, Ardèche, France. Science 286, 1999, p. 128-131.

DRIESCH VON DEN A. \& BOESSNECK J. 1975 - Schnittspuren an neolithischen Tierknochen. Ein Beitrag zur Schlachttierzerlegung in vorgeschichtlicher Zeit. Germania 53, p. 1-23.

FEREMBACH D., SCHWIDETZKY I. \& STLOUKAL M. 1979 - Empfehlungen für die Alters- und Geschlechtsdiagnose am Skelett. Homo 30, 1979, p. 1-32.

FERNANDEZ-JALVO Y., CARLOS DIEZ J, CACERES I., ROSELL J. 1999 - Human cannibalism in the Early Pleistocene of Europe (Gran Dolina, Sierra de Atapuerca, Burgos, Spain). Journal of Human Evolution 37, 1999, p. 591-622.

FRITZ C., MENU M., TOSELLO G. \& WALTER P. 1993 - La Gravure sur Os au Magdalénien : Étude Microscopique d'une Cote de la Grotte de la Vache (Commune D'Alliat, Ariége). Bulletin de la Société Préhistorique Francaise 90/6, 1993, p. 411-425.

GAMBIER D. \& HOUET F. 1993 - France. Upper Paleolithic. In : R. Oban (ed.), Homind Remains. An Up Date. December 1993 No 6. Laboratry of Anthropology and Human Genetics, Université Libre de Bruxelles, 1993.

GARRALDA, M.D. \& VANDERMEERSCH B. 2000 - Les Néandertaliens de la Grotte de Combe-Grenal (Domme, Fance). Paleo 12, 2000, p. 213-259.

GIESELER, W. \& CZARNETZKI, A. 1973 - Die menschlichen Skelettreste aus dem Magdalénien der Brillenhöhle. In : G. Riek, Das Paläolithikum der Brillenhöhle beiBlaubeuren (Schwäbische Alb). Forschungen und Berichte zur Vor - und Frühgeschichte in Baden-Württemberg 4/1, p. 165-168. Stuttgart: Müller \& Gräff, 1973.

GIETZ F.-J. 2001 - Die menschlichen Skelettreste aus dem paläolithischen Fundhorizont der Burghöhle Dietfurt. In : B. Gehlen, M. Heinen, A. Tillmann (Ed.) Zeit-Räume. Gedenkschriftfür Wolfgang Taute. Archäologis-che Berichte 14. Bonn: Habelt, p. 465-473.

GRAMSCH B. 1987 - Zeugnisse menschlicher Aktivitäten in Verbindung mit dem spätglazialen UrFund am Schlaatz bei Potsdam. Veröffentlichungen des Museums für Ur- und Frühgeschichte Potsdam 21, p. 47-51. Berlin: VEB Deutscher Verlag der Wissenschaften, 1987.

GUSTAVS, S. 1987 - Das Ur-Skelett von Potsdam-Schlaatz. Der archäologische Befund. Veröffentlichungen des Museums für Ur- und Frühgeschichte Potsdam 21, p. 31-36. Berlin: VEB Deutscher Verlag der Wissens-chaften, 1987.

HABENSTEIN R.W. \& LAMERS W.M. 1963 - Funeral Customs the World Over. Milwaukee: Bulfin, 1963.

HAHN J. 1988 - Der Steinzeitmensch auf der Alb. In : E. W. Bauer \& H. Schönnamsgruber (ed.), Das große Buch der Schwäbischen Alb, p. 96-112. Stuttgart: Konrad Theiss 1988.

HAIDLE M.N. \& ORSCHIEDT J. 1995 - Die Verwendung von Repliken bei der rasterelektronenmikroskopischen Untersuchung von osteologischem Material. Archäolo-gisches Korrespondenzblatt 25/2, 1995, p. 265-273.

HAMPERL H. 1967 - The Osteological Consequences of Scalping. In : D. Brothwell \& A.T.Sandison (ed.), Diseases in Antiquity. Injuries and Surgery of early Populations, p. 630-634. Illinois: Charles C. Thomas Springfield, 1967.

KAPICA Z. \& WIERCINSKI A. 1995 - Anthropological analysis of human skeletal remains from the Magdalenian period (younger paleolithic) recovered in Maszycka Cave, Olkusz Commune. In: S.K. 
Kozlowski, E. Sachse-Kozlowska, A. Marshack, T. Madeyska, H. Kierdorf, A. Lasota-Moskalewska, G. Jabubowski, M. Winiarska-Kabacinska, Z. Kapica \& A. Wiecinski, Maszycka cave a Magdalenian site in southern Poland. Jahrbuch des Römisch-Germanischen Zentralmuseums 40/1, 1995, p. 245-251.

KEMKES-GROTTENTHALER A. 1993 - Kritischer Vergleich osteomorphometrischerVerfahren zur Lebensalterbestimmung Erwachsener. Dissertation Mainz.

KNUßMANN R. (ed.) 1988 - Vergleichende Biologie des Menschen. Lehrbuch der Anthropologie und Humangenetik. Stuttgart : Gustav Fischer1988.

KOZLOWSKI S.K. \& SACHSE-KOZLOWSKA E. 1995 - Magdalenian family from the Maszycka Cave. In : S.K. Kozlowski, E. Sachse-Kozlowska, A. Marshack, T. Madeyska, H. Kierdorf, A. LasotaMoskalewska, G. Jabubowski, M. Winiarska-Kabacinska, Z. Kapica \& A. Wiecinski, Maszycka Cave a magdalenian site in southern Poland. Jahrbuch des Römisch-Germanischen Zentralmuseums 40/1, 1995, p. 115-205.

LAUXMANN, C. 1988 - Die Steinartefakte des magdalénienzeitlichen Fundhorizontes IV aus der Brillenhöhle bei Blaubeuren unter besonderer Berücksichtigung des Rohmaterials und der Grundproduktion. Unpublished M.A. thesis. Tübingen.

LAUXMANN C. \& SCHEER A. 1986 - Zusammensetzung von Silexartefakten- eine Methode zur Überprüfung archäologischer Einheiten. Fundberichte aus Baden-Württemberg 11, 1986, p. 101-131.

LE MORT F. 1986 - Le décharnement du cadavre au Paléolithique. Bulletin de la Société d' Anthropologie Sud-0uest 21/4, 1986, p. 205-215.

LE MORT F. 1988 - Le décharnement du cadavre chez les Néandertaliens : quelques exemples. Actes du Colloque International L' Homme de Néandertal, vol. 5 : La pensée. Liège, décembre 1986. Liège, ERAUL 32, 1988, p. 43-55.

LE MORT F - 1989 - Traces de décharnement sur les ossements néandertaliens de Combe-Grenal (Dordogne). Bulletin de la Société Préhistorique Française 86/3, 1989, p. 79-87.

LE MORT F. \& GAMBIER D. 1992 - Diversité du Traitement des Os Humains au Magdalénien : Un Exemple Particulier, le Cas du Gisement du Placard (Charente). In : J.-P. Rigaud, H. Laville \& B. Vandermeersch (eds.) Actes du colloque Le Peuplement Magdalénien, Chancelade, 10-15 oct.1988, p. 29-40. Paris: Éditions CNRS, 1992.

MARSHALL F. 1986. Implications of bone modification in a neolithic faunal assemblage for the study of early hominid butchery and subsistence practices. Journal of Human Evolution 15, 1986, p. 661-672.

MASSET C. 1989 - Age estimation on the basis of cranial sutures. In : Iscan, M.Y. (dir.) Age Markers in the Human Skeleton, p. 71-103. Springfield: Charles C. Thomas 1989.

MUNZELS C. 1987 - Umingmak, ein Moschusochsen-jagdplatz auf Banks Island, N.W.T, Canada. Archäozoologische Auswertung des Areals ID. Archäologische Forschungen auf Banks Island 1970-1975. Teil 2. Urgeschichtliche Materialhefte 5,2. Tübingen: Archaeologica Venatoria, 1987.

OLSEN S.L. 1989 - Solutré: A theoretical approach to the reconstruction of Upper Paleolithichunting strategies. Journal of Human Evolution 18, 1989, p. 295-327.

ORSCHIEDT J. 1998 - Die menschlichen Skelettreste. In : D.Schyle (ed.) Dasjungneolithische Erdwerk von Salzkotten-Oberntudorf, Kr. Paderborn. Die Ausgrabungen 1988 bis 1992. Bodenaltertümer Westfalens 33: 107-116. Mainz: Phillipp von Zabern, 1988. 
ORSCHIEDT J. 1999 - Manipulationen an menschlichen Skelettresten. Taphonomische Prozesse, Sekundärbes-tattungen oder Kannibalismus? Urgeschichtliche Materialhefte 13. Tübingen: Mo Vince, 1999.

OWSLEY D.W. \& BERRYMAN H.E. 1975 - Ethnographic and Archaeological Evidence of Scalping in the Southeastern United States. Tennessee Archaeologist 31, 1975, p. 41-58.

PATOU-MATHIS M. 1997 - Analyses taphonomique et palethnographique du materiel osseux de Krapina (Croatie) : Nouvelles donnees sur la faune et les restes humains. Préhistoire Européenne 10, 1997, p. 63-90.

PICKERING M.P. 1989 - Food for thought: an alternative to Cannibalism in the Neolithic. Australian Archaeologist 28, 1989, p. 35-39.

PICKERING T.R., WHITE T., TOTH N. 2000 - Brief communication: Cutmarks on a Plio-Pleistocene hominid from Sterkfontein, South Africa. American Journal of PhysicalAnthropology 111, 2000, p. 579-584.

POTTS R. \& SHIPMAN P. 1981 - Cutmarks made by stone tools on bones from Olduvai Gorge, Tanzania. Nature 291, 1981, p. 577-580.

RIEK G - 1973 - Das Paläolithikum der Brillenhöhle bei Blaubeuren (Schwäbische Alb). Forschungen und Berichte zur Vor - und Frühgeschichte in Baden-Württemberg 4/I Stuttgart: Müller \& Gräff, 1973.

RUSSELL M.D. 1987a - Bone Breakage in the Krapina Hominid Collection. American Journal of Physical Anthropology 72, 1987, p. 373-379.

RUSSELL M.D. 1987b - Mortuary practices at the Krapina Neandertal site. American Journalof Physical Anthropology 72, 1987, p. 381-397.

SCHMITZ R.W. \& PIEPER P. 1992 - Schnittspuren und Kratzer. Anthropogene Veränderungen am Skelett des Urmenschenfundes aus dem Neandertal- Vorläufige Befundaufnahme. Rheinisches Landesmuseum Bonn 2, 1992, p. 17-19.

SCHÜTZ C., TILLMANN A., WEINER J., RIEDER K.H. \& UNRATH G. 1990. Das Ingolstadt-Experiment: Zerlegung von Damwild mit Steinartefakten. Experimentelle Archäologie in Deutschland. Archäologische Mitteilungen aus Nordwestdeutschland 4, 1990, p. 232-256. Oldenburg: Isensee 1990.

SCHULER A. 1994. Die Schussenquelle. Eine Freilandstation des Magdalénien in Oberschwaben. Materialhefte zur Archäologie in Baden-Württemberg 27. Stuttgart: Konrad Theiss 1994.

SHIPMAN P. 1981 - Applications of scanning electron microscopy to taphonomic problems. In : A.M. Cantwell, J.B. Griffin \& N. Rothschild (eds.), The Research Potential ofAnthropological Museum Collections. Annals of the New York Academy of Science 376, 1981, p. 357-386.

SHIPMAN P. 1983 - Early hominid lifestyle: hunting and gathering or foraging and scavenging? In: J. Clutton-Brock \& C. Grigson (eds.), Animals and Archeology1: Huntersand their Prey. BAR International Series 163, p. 31-49. Oxford 1983.

SIBETH A. 1990 - Mit den Ahnen leben. Batak, Menschen in Indonesien. Stuttgart, London: Edition Mayer 1990.

SJøVOLD T. 1988 - Geschlechtsdiagnose am Skelett In : R. Knußmann (ed.), VergleichendeBiologie des Menschen. Lehrbuch der Anthropologie und Humangenetik, p. 444-480. Stuttgart: Gustav Fischer 1988.

SZILVASSY J. 1988 - Alterdiagnose am Skelett. In : R. Knußmann (ed.), Vergleichende Biologie des Menschen. Lehrbuch der Anthropologie und Humangenetik, p. 421-443. Stuttgart: Gustav Fischer 1988. 
TAUTE W. 1990 - Die Grabungen 1988 und 1989 in der Burghöhle Dietfurt an der oberen Donau, Gemeinde Inzigkofen-Vilsingen, Kreis Sigmaringen. Archäologische Ausgrabungenin BadenWürttemberg 1989, 1990, p. 38-44.

TRINKAUS E. 1985 - Cannibalism and burial at Krapina. Journal of Human Evolution 14/2, 1985, p. 203-216.

TROLLE-LASSEN T. 1987 - Human explonation of fur animals in Mesolithic Denmark - a case study. Archaeo-zoologia I/2, 1987, p. 85-102.

UEBELACKER D.H. 1978 - Human Skeletal Remains. Excavation, Analysis, Interpretation. Chicago: Aldine 1978.

ULLRICH H. 1978 - Kannibalismus und Leichenzerstüc-kelung beim Neandertaler von Krapina. In : M. Malez (ed.) Krapinski Pracovjek i Evolucija Hominida, p. 293-318, Zagreb 1978.

VALENSI P. 1991 - Études des Stries de Boucherie sur les ossements de Cerf elaphe des Niveaux supérieurs de la Grotte du Lazaret (Nice, Alpes-Maritimes). L’Anthropologie 95/4, 1991, p. 797-829.

VILLA P. 1992 - Cannibalism in Prehistoric Europe. Evolutionary Anthropology 1/3, 1992, p. 93-104.

VILLA P., COURTIN J., HELMER D., SHIPMAN P., BOUVILLE C. \& MAHIEU E. 1986a - Un cas de cannibalisme au Néolithique. Boucherie et rejet de restes humaines et animaux dans la grotte de Fontbrégoua á Salernes (Var). Gallia Préhistoire 29, 1986, p. 143-171.

VILLA P., BOUVILLE C., COURTIN J., HELMER D., MAHIEU E., SHIPMAN P., BELLUOMINI G. \& BRANCA M. 1986b - Cannibalism in the Neolithic. Science 233, 1986, p. 431-437.

VILLA P., COURTIN J. \& HELMER D. 1988 - Cannibalism in Old World Prehistory. Rivista di Anthropologia 66, 1988, p. 47-64.

WAHL J. 1982 - Leichenbranduntersuchungen. Ein Überblick über die Bearbeitungs und Aussagemöglich-keiten von Brandgräbern. Prähistorische Zeitschrift 57, 1982, p. 1-125.

WHITE T.D. 1986 - Cutmarks on the Bodo Cranium: A Case of prehistoric defleshing. American Journal of Physical Anthropology 69, 1986, p. 503-509.

\section{ABSTRACTS}

During excavations at the Brillenhöhle near Blaubeuren, a paleolithic cave site on the Swabian Alp, Baden-Württemberg, Southwest Germany, human skeletal remains of the Magdalenian were found in 1956. They were grouped inside a fire place in the centre of the cave. The skeletal remains were very fragmentary and consisted of an adult skullcap, numerous heavily damaged elements of the postcranial skeleton of three other adults and a few skeleton parts of an infant. It is to point out that long bones were missing at the site and that only small skeletal remains or bones broken into small pieces were found. During the first study of the bones, several cut marks were noticed on the remains. As a result, the find was interpreted as evidence for cannibalistic activity. A complete reexamination of the surfaces of all skeletal remains was undertaken using a scanning electron microscope (SEM). With the SEM, chop and scratch marks accompanying the cut marks were identified. A comparison with Magdalenian butchering marks on animal remains uncovered major discrepancies. The greatest difference is that on the human remains the frequency of cut marks was much more important than those discovered on contemporary animal remains. The scratch marks on the human bones show that they have been intensively cleaned from flesh. That means that the manipulation of the human bones was far more intense than the work on the animal bones. In addition to these anthropogenic manipulation marks, 
taphonomic processes are evident. The bone surfaces, especially on the skullcap, show erosion, and one skeletal element had a puncture mark left by the tooth of a carnivore. As the conditions for preservation are extremely good at the site, and carnivores had no evident means to influence them, the skeletal remains must have been at a different place before they finally came to the site. The finds' context and the high frequency of butchering and defleshing marks in combination with the evident selection of the skeletal elements allow an identification of the finds in the Brillenhöhle as a secondary burial of human skeletal remains.

Durant les fouilles menées à Brillenhöhle près de Blaubeuren, un site en grotte du Paléolithique dans le Jura Souabe (Baden-Württemberg, Allemagne du Sud-Ouest), des restes humains rapportés au Magdalénien ont été mis au jour en 1956. Ces vestiges étaient groupés dans une zone de combustion au milieu de la grotte. Les restes osseux étaient fragmentaires et consistaient en une calotte crânienne, des éléments nombreux, mais très endommagés, du squelette postcrânien de trois adultes différents et quelques restes squelettiques d'un enfant. Il faut noter qu'il n'y a pas de fragments d'os longs et que seuls des restes très fragmentés de petits os, furent découverts. Lors d'un premier examen des vestiges, quelques traces de découpe, ont été remarquées. La découverte fut alors interprétée comme le résultat d'une activité cannibale.

Un réexamen complet des surfaces de la totalité du matériel a été réalisé en utilisant un microscope électronique à balayage (MEB). Lors de cette étude, des marques de coups et de grattages, accompagnant les traces de découpes, furent identifiées. Une comparaison avec les traces de boucherie trouvées sur des vestiges de faune magdalénienne permet de souligner l'existence de très grandes divergences. La différence principale réside dans le fait que les traces de découpe sont deux fois plus nombreuses sur les restes humains que sur ceux, contemporains, de faune. Les marques de grattage sur les ossements humains montrent qu'ils ont été intensément nettoyés pour retirer la chair. Cela signifie que le travail effectué sur les ossements humains était beaucoup plus important que celui réalisé sur les ossements de faune. En plus de ces manipulations d'origine humaine, des traces d'atteintes d'ordre taphonomique sont évidentes. La surface des ossements, surtout la calotte crânienne, est érodée et une pièce osseuse présente une marque ponctiforme laissée par une dent de carnivore. Comme les conditions de préservation des vestiges archéologiques sont très bonnes dans le site, et que les activités des carnivores n'ont eu qu'une faible influence, les restes humains doivent avoir séjourné dans un endroit distinct de celui de leur découverte. Le contexte des découvertes, la haute fréquence de marques de boucherie et de décarnisation combinés à la sélection évidente des éléments squelettiques permet de supposer l'existence dans le site de Brillenhöhle d'une sépulture secondaire humaine. (Traduit par Bruno Maureille)

Während der Ausgrabungen in der Brillenhöhle bei Blaubeuren, einer paläolithischen Höhlenfundstelle auf der Schwäbischen Alp in Baden Württemberg, Südwestdeutschland wurden im Jahre 1956 menschliche Skelettreste aus dem Magdalenien entdeckt. Die Skelettreste fanden sich innerhalb einer Feuerstelle in der Mitte des Höhlenraumes. Die fragmentarischen Reste bestehen aus dem Schädeldach eines Erwachsenen und zahlreichen Resten des postkranialen Skelettes von drei weiteren Erwachsenen und einigen Skelettelementen eines Kindes. Bemerkenswerterweise fehlten Reste von Langknochen, lediglich kleine Knochen oder kleinere Bruchstücke wurden entdeckt. Während der ersten Untersuchung der Knochen wurden zahlreiche Schnittspuren festgestellt. Der Fund wurde daraufhin zunächst als Beleg für kannibalistische Aktivitäten interpretiert. Eine vollständige Neuuntersuchung aller Knochenoberflächen wurde mit Hilfe des Rasterelektronenmikroskopes (REM) durchgeführt. Bei der REM Untersuchung konnten neben Schnittspuren auch Schlag- und Kratzspuren identifiziert werden. Anhand eines Vergleiches mit Schlacht- und Zerlegungsspuren an Tierresten aus dem Magdalenien ließen sich deutliche Unterschiede erkennen. Der auffälligste Unterschied besteht in der hohen Schnittspurenfrequenz an den menschlichen Resten, diese war doppelt so hoch wie 
bei Tierknochen. Die Kratzspuren an den menschlichen Resten zeigen, dass diese intensiv von Weichteilen gereinigt wurden. Dies deutet darauf hin, dass die Manipulationen an den menschlichen Resten wesentlich intensiver als an Tierknochen durchgeführt wurden. Neben diesen anthropogenen Manipulationen liegen auch Hinweise auf taphonomische Prozesse vor. Die Knochenoberflächen sind vor allem am Schädeldach verwittert. Ein Skelettelement weist eine Bissspur eines Karnivoren auf. Da die Erhaltungsbedingungen in der Fundstelle sehr gut sind und Karnivoren die Fundsituation nicht beeinflusst haben, deutet dies darauf hin, dass sich die menschlichen Reste zuvor an einem anderen Ort befunden haben müssen, bevor sie in die Fundstelle eingebracht wurden. Der Fundkontext und die hohe Frequenz der Schlacht- und Zerlegungsspuren deuten zusammen mit einer deutlichen Selektion der Skelettreste auf eine sekundäre Bestattung menschlicher Skelettreste in der Brillenhöhle hin.

\section{INDEX}

Mots-clés: Paléolithique supérieur, Magdalénien, pratiques funéraires, sépulture secondaire, trace de découpe, cannibalisme, grotte, Allemagne du sud-ouest

Keywords: Upper Palaeolithic, Magdalenian, burial customs, secondary burial, cutmarks, cannibalism, cave site, Southwest Germany

Schlüsselwörter: Jungpaläolithikum, Magdalenien, Bestattungssitten, Sekundärbestatttung, Schnittspuren, Kannibalismus, Höhle, Südwestdeutschland

\section{AUTHOR}

\section{JÖRG ORSCHIEDT}

Universität Hamburg, Archäologisches Institut, Abteilung I: Vor- und Frühgeschichtliche Archäologie, Johnsallee 35, 20148 Hamburg - e-mail: orschiedt@uni-hamburg.de 